\title{
IN VIVO STUDIES OF THE ROLE OF ALBUMIN IN ENDOGENOUS AND HEPARIN-ACTIVATED LIPEMIA-CLEARING IN NEPHROTIC RATS ${ }^{1}$
}

\author{
BY RAY H. ROSENMAN AND MEYER FRIEDMAN
}

\author{
(From the Harold Brunn Institute, Mount Zion Hospital, San Francisco 15, Calif.)
}

(Submitted for publication June 15, 1956; accepted January 17, 1957)

In a previous study (1) heparin was found to inhibit the rise of plasma lipids and cholesterol occurring in rats with nephrosis experimentally induced by injection of anti-rat kidney serum (AKS). Such inhibition was marked when heparin was administered prior to and immediately after the injection of AKS, but of much lesser degree when administered to the chronic nephrotic rat with established hypoalbuminemia and hyperlipemia. A similar slight or absent anti-lipemic response to heparin has been observed in some human subjects with nephrosis (2). This suggested to us that perhaps the inhibitory action of heparin necessitated the presence of a larger concentration of plasma albumin than was present in the chronic nephrotic rat.

Therefore a second study (3) was done in which bovine serum albumin was infused into rats during both the induction and chronic phases of experimental nephrosis. This was found to be far more effective than heparin in respectively preventing and correcting the hyperlipemia otherwise occurring in such rats. However, the infusion of albumin was not found capable of completely normalizing the plasma lipids of the nephrotic animal unless it concomitantly was nephrectomized.

This suggested that the accumulation of lipids in the plasma of the nephrotic rat is due not only to a quantitative deficiency of plasma albumin (3) but also to the excessive renal loss of some other essential plasma constituent of the lipid-clearing mechanism which might be escaping pari passu, either separately or combined with the escaping albumin. If this substance were heparin, or its plasma equivalent, the combined administration of heparin and albumin would be expected to be

1 Aided by Grants from the National Institute of Arthritis and Metabolic Diseases of the National Institutes of Health, (A-46, C-4), the American Heart Association and the San Francisco Heart Association. completely effective in normalizing the plasma lipids of the nephrotic rat. This was found to be true in the present study of such combined treatment, the data also providing an in vivo demonstration of the essential role of adequate plasma albumin for both endogenous and heparin-activated processes of lipemia-clearing.

\section{METHODS AND RESULTS}

Adult, male rats (Long-Evans) were used in these studies. Pooled rabbit anti-rat kidney serum (AKS) was prepared as described by Heymann and Lund (4) and assayed in preliminary studies by its ability to induce hypoalbuminemia, hyperlipemia and hypercholesteremia within 18 hours after its intravenous injection. Continuous intravenous infusions were administered by a special constant infusion apparatus designed to inject $0.25 \mathrm{ml}$. per hour ( $6.0 \mathrm{ml}$. per 24 hours) through an exteriorized polyethylene cannula placed in an inferior lumbar vein during a preliminary operation accomplished under ether anesthesia. The injected solutions were either freshly prepared aqueous bovine serum albumin ( 30 per cent) or sodium chloride ( 0.9 per cent), the latter being used since it was previously found to induce a degree of hemodilution in nephrotic rats comparable to that induced by the albumin solution (3). In certain instances $5 \mathrm{mg}$. of sodium heparin was added to each 6-ml. aliquot of infusion solution. Plasma total lipids, total cholesterol, and albumin were determined by the methods previously described (3).

\section{A. The effect of albumin-heparin infusion on plasma lipids during the induction of the nephrotic state.}

Each of 50 rats was prepared for intravenous infusion and injected with AKS (1 ml.). During the ensuing 24 hours, nine rats (Group I) were continuously infused with six ml. saline-heparin solution, as described above, and nine rats (Group II) with albumin-heparin solution. For control purposes 19 rats (Group III) were infused with albumin solution and 13 rats (Group IV) with saline solution, without added heparin. All rats were bled for plasma total lipids, total cholesterol and albumin at the end of the 24-hour infusion interval, and hematocrits were determined in those infused with saline (Group IV) and albumin (Group III). 
TABLE I

The effect of continuous 24-hour infusion of albumin and heparin on plasma lipids of rats concomitantly injected with antikidney serum

\begin{tabular}{|c|c|c|c|c|c|c|c|}
\hline \multirow[b]{3}{*}{ Group } & \multirow[b]{3}{*}{ Infusion fluid } & \multirow[b]{3}{*}{$\begin{array}{c}\text { No. of } \\
\text { rats }\end{array}$} & \multirow[b]{3}{*}{$\begin{array}{c}\text { Aver. } \\
\text { wt. } \\
(\mathrm{gm.} .)\end{array}$} & \multicolumn{4}{|c|}{ Average plasma concentrations* } \\
\hline & & & & \multicolumn{2}{|c|}{ Total cholesterol } & \multirow{2}{*}{$\begin{array}{c}\text { Total lipids } \\
\text { concentration } \\
(m g . / 100 \mathrm{ml} .)\end{array}$} & \multirow[b]{2}{*}{$\underset{(\mathrm{gm} . / 100 \mathrm{mb} .)}{\text { Albumin }}$} \\
\hline & & & & $\begin{array}{l}\text { Concentration } \\
(m g . / 100 \mathrm{ml} .)\end{array}$ & $\underset{\substack{\text { Average increaset } \\
(\mathrm{mg} . / 100 \mathrm{ml} .)}}{ }$ & & \\
\hline \multicolumn{8}{|c|}{ Rats injected with antikidney serum } \\
\hline $\mathbf{I}$ & $\begin{array}{c}\text { Saline + Heparin } \\
\text { Range: } \\
\text { S.E. Mean: }\end{array}$ & 9 & 161 & $\begin{array}{c}125 \\
(94-162) \\
\pm 7.8\end{array}$ & $\begin{array}{c}+63 \\
(+32-100) \\
\pm 7.7\end{array}$ & $\begin{array}{c}318 \\
(219-365) \\
\pm 15.6\end{array}$ & $\begin{array}{c}1.1 \\
(0.9-1.7) \\
\pm 0.12\end{array}$ \\
\hline II & $\begin{array}{l}\text { Bovine Albumin }+ \\
\text { Heparin } \\
\text { Range: } \\
\text { S.E. Mean : }\end{array}$ & 9 & 160 & $\begin{array}{c}65 \\
(30-89) \\
\pm 6.9\end{array}$ & $\begin{array}{c}+3 \\
(+27-(-32)) \\
\pm 6.8\end{array}$ & $\begin{array}{c}254 \\
(191-303) \\
\pm 14.5\end{array}$ & $\begin{array}{l}4.0 \\
(2.5-5.3) \\
\pm 0.43\end{array}$ \\
\hline III & $\begin{array}{l}\text { Bovine Albumin } \\
\text { Range: } \\
\text { S.E. Mean: }\end{array}$ & 19 & 158 & $\begin{array}{c}108 \\
(81-131) \\
\pm 9.3\end{array}$ & $\begin{array}{c}+46 \\
(+19-69) \\
\pm 2.9\end{array}$ & $\begin{array}{c}297 \\
(238-349) \\
\pm 7.3\end{array}$ & $\begin{array}{c}3.9 \\
(3.1-5.1) \\
\pm 0.68\end{array}$ \\
\hline IV & $\begin{array}{l}\text { Saline } \\
\text { Range: } \\
\text { S.E. Mean: }\end{array}$ & 13 & 162 & $\begin{array}{c}153 \\
(117-187) \\
\pm 6.3\end{array}$ & $\begin{array}{c}+91 \\
(+55-125) \\
\pm 6.3\end{array}$ & $\begin{array}{c}413 \\
(275-540) \\
\pm 15.4\end{array}$ & $\begin{array}{l}1.2 \\
(0.5-1.5) \\
\pm 0.10\end{array}$ \\
\hline \multicolumn{8}{|c|}{ Control rats injected with normal rabbit serum } \\
\hline V & $\begin{array}{l}\text { Saline } \\
\quad \text { Range: } \\
\text { S.E. Mean: }\end{array}$ & 10 & 164 & $\begin{array}{c}62 \\
(52-70) \\
\pm 2.2\end{array}$ & & $\begin{array}{c}191 \\
(142-228) \\
\pm 6.2\end{array}$ & $\begin{array}{c}2.3 \\
(2.0-2.6) \\
\pm 0.11\end{array}$ \\
\hline
\end{tabular}

* At completion of continuous 24-hour infusion $(6.0 \mathrm{ml}$. per rat).

$\dagger$ Increment in excess of $62 \mathrm{mg}$. per $100 \mathrm{ml}$. (Group V).

Control plasma concentrations were established by bleeding 10 other normal rats (Group V) 24 hours after injection of $1.0 \mathrm{ml}$. of normal rabbit serum and infusion of saline.

In Table $I$ it can be seen that the injection of AKS induced in 24 hours in the control rats (Group IV) a fall of plasma albumin to an average of $1.2 \mathrm{gm}$. per $100 \mathrm{ml}$., with an associated average increase of plasma lipids to $413 \mathrm{mg}$. per $100 \mathrm{ml}$. and of plasma cholesterol to $153 \mathrm{mg}$. per $100 \mathrm{ml}$. The rats infused with heparin (Group I) exhibited a comparable fall of plasma albumin (average: $1.1 \mathrm{gm}$. per $100 \mathrm{ml}$.$) , but a significantly lesser rise of$ plasma lipids (average: $318 \mathrm{mg}$. per $100 \mathrm{ml}$.) and of cholesterol (average: $125 \mathrm{mg}$. per $100 \mathrm{ml}$.). Since the infusion of heparin did not affect the fall of plasma albumin in these rats, there is no evidence that the observed lipemia-inhibitory effects were due to any effect of heparin on the immune mechanism by which AKS induced nephrosis, as may possibly occur under certain experimental circumstances $(1,5)$.

The infusion of albumin (Group III) prevented the fall of plasma albumin (average: $3.9 \mathrm{gm}$. per $100 \mathrm{ml}$.) and, as observed previously (3), even more effectively inhibited the rise of plasma lipids (average: $297 \mathrm{mg}$. per $100 \mathrm{ml}$.) and of cholesterol $(108 \mathrm{mg}$. per $100 \mathrm{ml}$.) otherwise induced by AKS injection. However, only the combined infusion of heparin and albumin (Group II) proved completely effective in inhibiting the AKSinduced rise of plasma lipids (average: $254 \mathrm{mg}$. per 100 $\mathrm{ml}$.) and cholesterol (average: $65 \mathrm{mg}$. per $100 \mathrm{ml}$.). These rats exhibited an average plasma albumin of 4.0 mg. per $100 \mathrm{ml}$., similar to those infused only with albu$\min$ (Group III). Moreover, the observed results could not be ascribed to any significant difference of induced hemodilution since the average hematocrit was 44 (Range: 41 to 48 ) in the rats infused with saline (Group IV), and 40 (Range: 38 to 41 ) in the albumin-infused rats (Group III).

\section{B. The effect of albumin-heparin infusion on the plasma lipids of chronic nephrotic rats}

The previous experiment indicated that heparin only incompletely inhibited the rise of plasma lipids during the induction of the nephrotic state, and even less effectively inhibited the rise of plasma cholesterol. Similarly, as observed previously (3), albumin infusion was not completely effective in inhibiting the rise of plasma lipid and cholesterol unless it was combined with heparin. In view of the apparent need of both substances in preventing the occurrence of AKS-induced hyperlipemia and hypercholesteremia, it appeared of importance to us to determine whether the combination of heparin and albumin also was necessary to correct an already established hyperlipemia and hypercholesteremia in chronic nephrotic rats.

Each of a series of 46 rats was injected with one $\mathrm{ml}$. AKS. Four days later the rats were divided into four 
TABLE II

The effect of continuous 24-hour infusion of albumin and heparin on plasma lipids of chronic nephrotic rats four days after injection of antikidney serum

\begin{tabular}{|c|c|c|c|c|c|c|c|c|}
\hline \multirow[b]{4}{*}{ Group } & \multirow[b]{4}{*}{ Infusion fluid* } & \multirow[b]{4}{*}{$\begin{array}{l}\text { No. of } \\
\text { rats }\end{array}$} & \multirow{4}{*}{$\begin{array}{c}\text { Aver. } \\
\text { wt. } \\
\text { (gm.) }\end{array}$} & \multicolumn{5}{|c|}{ Average plasma concentrations } \\
\hline & & & & \multirow{3}{*}{$\frac{\text { Pre-infusion }}{\begin{array}{c}\text { Total } \\
\text { cholesterol } \\
(m \mathrm{mg} . / 100 \mathrm{ml} .)\end{array}}$} & \multicolumn{4}{|c|}{ Post-infusion } \\
\hline & & & & & \multicolumn{2}{|c|}{ Total cholesterol } & \multirow[b]{2}{*}{$\begin{array}{l}\text { Total lipids } \\
(\mathrm{mg} . / 100 \mathrm{ml} .)\end{array}$} & \multirow[b]{2}{*}{$\underset{(\mathrm{gm} . / 100 \mathrm{ml} .)}{\text { Albumin }}$} \\
\hline & & & & & $\begin{array}{l}\text { Concentration } \\
(m g . / 100 ~ m l .)\end{array}$ & $\underset{(m g . / 100 \mathrm{ml} .)}{\text { Average change }}$ & & \\
\hline I & $\begin{array}{l}\text { Saline + Heparin } \\
\text { Range: } \\
\text { S.E. Mean: }\end{array}$ & 9 & 186 & $\begin{array}{c}206 \\
(163-226) \\
\pm 11.0\end{array}$ & $\begin{array}{c}217 \\
(157-290) \\
\pm 10.4\end{array}$ & $\begin{array}{c}+11 \\
(+60-(-52)) \\
\pm 11.1\end{array}$ & $\begin{array}{c}429 \\
(262-568) \\
\pm 20.6\end{array}$ & $\begin{array}{c}1.1 \\
(0.8-1.4) \\
\pm 0.30\end{array}$ \\
\hline II a) & $\begin{array}{l}\text { Bovine Albumin }+ \\
\text { Heparin } \\
\text { Range: } \\
\text { S.E. Mean: }\end{array}$ & 8 & 180 & $\begin{array}{c}224 \\
(168-283) \\
\pm 14.3\end{array}$ & $\begin{array}{c}66 \\
(55-82) \\
\pm 3.2\end{array}$ & $\begin{array}{c}-158 \\
(-98-(-223)) \\
\pm 14.9\end{array}$ & $\begin{array}{c}243 \\
(186-302) \\
\pm 9.6\end{array}$ & $\begin{array}{c}3.2 \\
(2.0-4.7) \\
\pm 0.16\end{array}$ \\
\hline D) & $\begin{array}{l}\text { Heparin } \\
\text { Range: }\end{array}$ & 4 & 170 & $\begin{array}{c}279 \\
(181-423)\end{array}$ & $\begin{array}{c}348 \\
(195-501)\end{array}$ & $\begin{array}{c}+69 \\
(+8-221)\end{array}$ & $\begin{array}{c}581 \\
(415-954)\end{array}$ & $\begin{array}{c}1.0 \\
(0.7-1.2)\end{array}$ \\
\hline III & $\begin{array}{l}\text { Bovine Albumin } \\
\text { Range: } \\
\text { S.E. Mean: }\end{array}$ & 11 & 160 & $\begin{array}{c}223 \\
(167-278) \\
\pm 11.6\end{array}$ & $\begin{array}{c}116 \\
(54-218) \\
\pm 15.0\end{array}$ & $\begin{array}{c}-107 \\
(-27-(-203)) \\
\pm 14.4\end{array}$ & $\begin{array}{c}331 \\
(240-510) \\
\pm 26.6\end{array}$ & $\begin{array}{c}3.0 \\
(2.3-4.4) \\
\pm 0.20\end{array}$ \\
\hline IV & $\begin{array}{l}\text { Saline } \\
\quad \text { Range: } \\
\text { S.E. Mean: }\end{array}$ & 14 & 159 & $\begin{array}{c}221 \\
(142-281) \\
\pm 15.5\end{array}$ & $\begin{array}{c}220 \\
(135-287) \\
\pm 16.9\end{array}$ & $\begin{array}{c}-1 \\
(+48-(-44)) \\
+8.6\end{array}$ & $\begin{array}{c}550 \\
(415-662) \\
\pm 17.7\end{array}$ & $\begin{array}{c}1.1 \\
(0.6-1.4) \\
\pm 0.16\end{array}$ \\
\hline
\end{tabular}

* Six ml. per 24 hours.

groups and prepared for intravenous infusion. During the ensuing 24 hours nine of the rats (Group I) were continuously infused with saline-heparin and 12 others (Group II) with albumin-heparin solution. The remaining rats served as controls, 11 (Group III) being infused only with albumin and 14 (Group IV) only with saline.

In order to obviate the effect of initial removal of any significant amount of blood, the rats were bled only for plasma total cholesterol preoperatively. On completion of the 24-hour infusion all rats again were bled for determination of plasma total lipids, cholesterol and albumin.

The results are shown in Table II. The rats infused with saline containing heparin (Group I) exhibited an average plasma albumin of $1.1 \mathrm{gm}$. per $100 \mathrm{ml}$. at the end of the infusion interval. During this interval no significant change occurred in their average plasma cholesterol, which rose an average of $31 \mathrm{mg}$. per $100 \mathrm{ml}$. in six of the rats and fell an average of $30 \mathrm{mg}$. per $100 \mathrm{ml}$. in the remaining three rats. The respective saline-infused controls (Group IV) exhibited a comparable average plasma albumin of $1.1 \mathrm{gm}$. per $100 \mathrm{ml}$. and, as in the above rats, the infusion of saline failed to alter the average plasma cholesterol, which rose an average of $29 \mathrm{mg}$. per $100 \mathrm{ml}$. in six and fell an average of $19 \mathrm{mg}$. per 100 $\mathrm{ml}$. in eight of these rats. However, the average plasma total lipids of these two groups of rats was $429 \mathrm{mg}$. per $100 \mathrm{ml}$. and $550 \mathrm{mg}$. per $100 \mathrm{ml}$., respectively, indicating a moderate heparin-induced lowering of total plasma lipids. The combined infusion of heparin and albumin increased the plasma albumin content of only eight of the 12 rats so treated (Group II a), to an average of
$3.2 \mathrm{gm}$. per $100 \mathrm{ml}$. This was associated with a marked lowering of the plasma lipids of these eight rats to an average of $243 \mathrm{mg}$. per $100 \mathrm{ml}$., with an associated marked fall of their plasma cholesterols to normal levels averaging $66 \mathrm{mg}$. per $100 \mathrm{ml}$. That this response could not be ascribed only to the anti-lipemic effect of the albumin infusion per se (3) was shown by comparison with the respective control rats infused only with albumin (Group III) and which exhibited a comparable rise of plasma albumin (average: $3.0 \mathrm{gm}$. per $100 \mathrm{ml}$.) during the experimental interval, but a lesser fall of plasma lipids to an average of $331 \mathrm{mg}$. per $100 \mathrm{ml}$., and of cholesterol to an average of $116 \mathrm{mg}$. per $100 \mathrm{ml}$. The essential nature of adequate albumin for heparin-induced lipemia-clearing was particularly well shown by the findings in the remaining four of the 12 rats similarly infused with combined albumin-heparin (Group II b) but in which there failed to develop a rise of plasma albumin (average: $1.0 \mathrm{gm}$. per $100 \mathrm{ml}$.) which exceeded those of the saline-infused controls. Thus, despite the infusion of heparin, these rats exhibited plasma lipid levels averaging $581 \mathrm{mg}$. per $100 \mathrm{ml}$., comparable to those of the salineinfused controls (Group IV), and a further rise of their plasma cholesterols from an average of $279 \mathrm{mg}$. per 100 $\mathrm{ml}$. to an average of $348 \mathrm{mg}$. per $100 \mathrm{ml}$. occurred during the 24-hour experimental interval.

\section{DISCUSSION}

Albumin has been shown (6-10) clearly to provide the vehicle for the transport of the fatty acids 
released during the hydrolysis of triglyceride substrates, and a relative deficiency of albumin has been shown (6-8) in vitro to block such lipolysis. Since the hydrolysis of plasma triglycerides appears, moreover, to be a prerequisite for clearance of lipid from the plasma $(11,12)$, the retention of excess lipid in the plasma would be expected in certain states characterized by the rapid loss and sustained depletion of plasma albumin. Consonant with this is our earlier finding (13) that the nephrotic state in rats is characterized by an isolated accumulation of excess lipid which is confined to their plasma. The essential role of albumin for the maintenance of endogenous processes of lipolysis and lipid-clearing from the plasma was confirmed in vivo by our recent demonstration (3) of the causal relationship between hypoalbuminemia and hyperlipemia in the experimentally nephrotic rat. The albumin deficiency blocks lipolysis and consequently also the egress of lipid from the plasma was also confirmed in the present studies in which the infusion of albumin again was shown to induce the rapid clearance of excess lipid from the plasma of nephrotic rats exhibiting hypoalbuminemia and hyperlipemia.

The lipemia-clearing induced by heparin administration in nephrotic human subjects has been found to be of limited magnitude and occasionally even absent (2). A similar limited anti-lipemic response to heparin was observed previously by us (1) in chronic nephrotic rats. In the present studies it was shown that this limited ability of heparin to clear excess lipids from the nephrotic rat's plasma is due to the sustained deficiency of albumin in such plasma, confirming in vitro demonstrations $(6-10)$ of the essentiality of adequate albumin for heparin-activated processes of lipolysis and lipemia-clearing. It was also shown that the rate of clearance of excess lipid from the nephrotic rat's plasma during the infusion of albumin was considerably augmented by the concomitant administration of heparin. This is consonant with the belief (14-19) that heparin-induced, lipemiaclearing is simply an acceleration of the normally occurring lipolytic processes. The observed response to heparin-albumin infusion also indicated the ability of the nephrotic rat to form potent lipemia-clearing factor and failed to confirm the presence in nephrotic rat's plasma of some "clear- ing-factor inhibitor," as has been suggested by others (20).

It is likely that the clearance of excess cholesterol from the nephrotic rat's plasma, following administration of albumin and/or heparin, is secondary to the effects of these substances on the hydrolysis of triglycerides (10), since in turn, the accumulation of excess cholesterol in nephrotic plasma is probably secondary to the hypertriglyceridemia induced by the albumin deficiency (3). Thus, in the normal rat (21), progressive hypercholesteremia occurs when a sustained rise of plasma triglycerides is induced by the latter's continuous intravenous infusion. Since a progressive rise of plasma cholesterol also occurs in normal rats that are continuously infused with phospholipids (22), the hypercholesteremia in nephrotic plasma may, in part, be secondary to the hyperphospholipemia which also occurs in the nephrotic state. It is likely $(21,23-25)$ that the increment of excess cholesterol and phospholipid in nephrotic plasma, as in other hyperlipemic states, is "dissolved" in the excess insoluble triglycerides present in such plasma. The clearing of excess cholesterol from the plasma of the nephrotic rats infused with albumin or albumin-heparin would thus appear to be secondary to the dissolution of triglycerides known to be accomplished by such treatment $(10,24,25)$.

In the present studies, as observed previously (3), the infusion of albumin was not found capable either of completely preventing the rise of plasma lipids and cholesterol induced by injection of antikidney serum, or of completely correcting the hyperlipemia and hypercholesteremia of chronic nephrotic rats. However, since the combined administration of heparin and albumin was found completely effective in this regard, it is likely that this partial failure on the part of albumin administration was not due to the use of "prepared" bovine serum albumin, rather than more physiological rat serum albumin, or to the presence of some clearing-factor inhibitor in the nephrotic rat's plasma (20). On the other hand, when the chronic nephrotic rat was nephrectomized, and then infused with albumin (3), as complete a normalization of the plasma lipids occurred as was observed presently in intact nephrotic rats infused concomitantly with albumin and 
heparin. This suggests that a causal factor in the occurrence of nephrotic hyperlipemia, other than the quantitative deficiency of plasma albumin (3), may be the renal loss of "clearing-factor" or some co-factor, occurring alone or in combination with escaping albumin. An additional factor would appear to be the short intravascular existence of any given albumin molecule. Thus, in certain of the treated chronic nephrotic rats, the renal loss of infused albumin occurred so rapidly $(3,26)$ as to preclude any rise of plasma albumin, and in this instance no lipemia-clearing was induced by the injected albumin or by the concurrently administered heparin.

\section{SUMMARY}

The effect of administration of heparin and albumin, alone or in combination, upon the plasma lipids of nephrotic rats was studied during both the induction and chronic phases of experimental nephrosis induced by antikidney serum injection. It was found that heparin administration induced only a minimal lipemia-clearing response in severely hypoalbuminemic rats, unless albumin was simultaneously administered. The concurrent administration of heparin markedly augmented the ability of infused albumin to correct the hyperlipemia and hypercholesteremia of the nephrotic rat. It was suggested that an additional causal factor underlying nephrotic hyperlipemia, other than deficiency of plasma albumin, may be the renal loss in such rats of "clearing-factor" or some co-factor essential to lipolytic processes.

The data provide an in vivo confirmation of the essential role of albumin for endogenous and heparin-activated lipemia-clearing and are consonant with the belief that heparin effects lipemiaclearing by accelerating normally occurring lipolytic processes.

\section{ACKNOWLEDGMENT}

We wish to express our appreciation to Armour \& Company for the generous supplies of bovine serum albumin provided for this study.

\section{REFERENCES}

1. Rosenman, R. H., Solomon, B., Byers, S., and Friedman, M., Arresting effect of heparin upon experi- mental nephrosis in rats. Proc. Soc. Exper. Biol. \& Med., 1954, 86, 599.

2. Herzstein, J., Wang, C. I., and Adlersberg, D., Effect of heparin on plasma lipid partition in man: Studies in normal persons and in patients with coronary atherosclerosis, nephrosis and primary hyperlipemia. Ann. Int. Med., 1954, 40, 290.

3. Rosenman, R. H., Friedman, M., and Byers, S. O., The causal role of plasma albumin deficiency in experimental nephrotic hyperlipemia and hypercholesteremia. J. Clin. Invest., 1956, 35, 522.

4. Heymann, W., and Lund, H. Z., Nephrotic syndrome in rats. Pediatrics, 1951, 7, 691.

5. Kleinerman, J., Effect of heparin on experimental nephritis in rabbits. Federation Proc., 1954, 13, 435.

6. Robinson, D. S., and French, J. E., The role of albu$\min$ in the interaction of chyle and plasma in the rat. Quart. J. Exper. Physiol., 1953, 38, 233.

7. Gordon, R. S., Jr., Boyle, E., Brown, R. K., Cherkes, A., and Anfinsen, C. B., Role of serum albumin in lipemia clearing reaction. Proc. Soc. Exper. Biol. \& Med., 1953, 84, 168.

8. Seifter, J., and Baeder, D. H., Influence of calcium and serum albumin on clearing of lipemic dog plasma in vitro. Proc. Soc. Exper. Biol. \& Med., 1955, 89, 511.

9. McDaniel, R. A., and Grossman, M. I., Paper electrophoretic study of $\mathrm{C}^{16}$ fat emulsion cleared from post-heparin rat plasma. Proc. Soc. Exper. Biol. \& Med., 1955, 89, 442.

10. Gordon, R. S., Jr., Interaction between oleate and the lipoproteins of human serum. J. Clin. Invest., 1955, 34, 477.

11. Grossman, M. I., Straub, I., and Decrease, W., Clearing by heparin of plasma made lipemic with synthetic fat emulsions. Am. J. Physiol., 1952, 171, 730.

12. Spitzer, J. J., Removal and mobilization of lipids in normal and hepatectomized dogs. Am. J. Physiol., 1955, 181, 83.

13. Rosenman, R. H., Friedman, M., and Byers, S. O., The distribution of cholesterol and total lipids in the nephrotic rat. J. Clin. Invest., 1955, 34, 700.

14. Pierce, F. T., The interconversion of serum lipoproteins in vivo. Metabolism, 1954, 3, 142.

15. Levy, S. W., and Swank, R. L., The effects of in vivo heparin on plasma esterase activity and lipaemia clearing. J. Physiol., 1954, 123, 301.

16. Bragdon, J. H., and Havel, R. J., In vivo effect of anti-heparin agents on serum lipids and lipoproteins. Am. J. Physiol., 1954, 177, 128.

17. Grossman, M. I., Palm, L., Becker, G. H., and Moeller, H. C., Effect of lipemia and heparin on free fatty acid content of rat plasma. Proc. Soc. Exper. Biol. \& Med., 1954, 87, 312.

18. Grossman, M. I., Moeller, H. C., and Palm, L., Effect of lipemia and heparin on free fatty acid concen- 
tration of serum in humans. Proc. Soc. Exper. Biol. \& Med., 1955, 90, 106.

19. Korn, E. D., Properties of clearing factor obtained from rat heart acetone powder. Science, 1954, 120, 399.

20. Seifter, J., and Baeder, D. H., Lipemia clearing by hyaluronidase, hyaluronate, and desoxycorticosterone, and its inhibition by cortisone, stress, and nephrosis. Proc. Soc. Exper. Biol. \& Med., 1954, 86, 709.

21. Friedman, M., and Byers, S., Role of hyperlipemia in the genesis of hypercholesteremia. Proc. Soc. Exper. Biol. \& Med., 1955, 90, 496.

22. Friedman, M., and Byers, S. O., Role of hyperphospholipidemia and neutral fat increase in plasma in the pathogenesis of hypercholesteremia. Am. J. Physiol., 1956, 186, 13.

23. Byers, S. O., and Friedman, M., The fractionation of cholesterol in body fluids by means of solvent extraction. J. Clin. Invest., 1956, 35, 405.

24. Albrink, M. J., Glenn, W. W. L., Peters, J. P., and Man, E. B., The transport of lipids in chyle. J. Clin. Invest., 1955, 34, 1467.

25. Albrink, M. J., Man, E. B., and Peters, J. P., The relation of neutral fat to lactescence of serum. J. Clin. Invest., 1955, 34, 147.

26. Drabkin, D. L., and Marsh, J. B., Metabolic channeling in experimental nephrosis. I. Protein and carbohydrate metabolism. J. Biol. Chem., 1955, 212, 623. 